\title{
Routes Planning Models for Railway Transport Systems in Relation to Passengers' Demand
}

\author{
Alessandro Severino $^{1}(\mathbb{D})$, Larysa Martseniuk ${ }^{2, *(\mathbb{D})}$, Salvatore Curto ${ }^{3} \mathbb{D}$ and Larysa Neduzha ${ }^{4}(\mathbb{D}$ \\ 1 Department of Civil Engineering and Architecture, University of Catania, 95123 Catania, Italy; \\ alessandro.severino@unict.it \\ 2 Department of Economics and Management, Dnipro National University of Railway Transport Named after \\ Academician V. Lazaryan, Lazaryan St. 2, 49010 Dnipro, Ukraine \\ 3 Faculty of Engineering and Architecture, Kore University of Enna, 94100 Enna, Italy; \\ salvatore.curto@unikorestudent.it \\ 4 Department of Theoretical and Structural Mechanics, Dnipro National University of Railway Transport \\ Named after Academician V. Lazaryan, Lazaryan St. 2, 49010 Dnipro, Ukraine; nlorhen@i.ua \\ * Correspondence: rwinform1@ukr.net
}

check for updates

Citation: Severino, A.; Martseniuk, L.; Curto, S.; Neduzha, L. Routes Planning Models for Railway Transport Systems in Relation to Passengers' Demand. Sustainability 2021, 13, 8686. https://doi.org/ $10.3390 /$ su13168686

Academic Editor: Marco Guerrieri

Received: 19 May 2021

Accepted: 21 July 2021

Published: 4 August 2021

Publisher's Note: MDPI stays neutral with regard to jurisdictional claims in published maps and institutional affiliations.

Copyright: (c) 2021 by the authors. Licensee MDPI, Basel, Switzerland. This article is an open access article distributed under the terms and conditions of the Creative Commons Attribution (CC BY) license (https:/ / creativecommons.org/licenses/by/ $4.0 /)$.

\begin{abstract}
Nowadays, transport systems efficiency plays a key role for communities' liveability and economy, being in addition an important factor in the economic integration of countries. The purpose of the article is to develop multi-stage models of tourist activities for optimizing the development of operating companies. For the implementation of models, the authors evolved the relevant system of organizational-functional support for the development of railway tourism. The research will enable us to take into consideration risks when planning tourist routes by railway, determine the order of construction or start of routes, and assess their profitability. This will provide to earn the expected incomes of all interested parties in tourist activities for the specified period. The authors created economic-mathematical models of the discrete optimal planning of the railway tourism operations. This takes into account conditions of risks and cooperation, and allows to determine which sets of effective routes are the most profitable ones. The results of the realization of the developed models include the task of the succession of the tourist route introduction according to the present and future infrastructure, availability of the rolling stock, etc. In this, consideration is given to obtaining maximum profit from tourism businesses for every participant during an established period.
\end{abstract}

Keywords: railway transport; tourism; pandemic; passenger transportation; multi-stage models; profitability; investments

\section{Introduction}

The transport sector has always acted as a main element for development and economic growth of any country and is a fundamental component of its infrastructures. Efficient operation of transport systems is a prerequisite for national security, development of foreign economic spheres of activity, ensuring living standards of the population, etc. Nowadays, transport is an important factor in the economic integration of countries and the development of international cooperation. It provides "communication", including cultural exchange (both between continents and individual regions), and promotes the fulfillment of the aesthetic needs in all segments of the population [1].

Railway transport is fundamental to the world economy as it moves passengers and tourists, as well as hauls freight and luggage [2,3]. Factors such as overload and accidents on roads, air pollution, noise from vehicles, etc. have made railway systems one of the main components in reliable mobility of the population $[4,5]$.

Railway transport has the following number of advantages over other modes [6]:

- $\quad$ Reducing adverse effects on climatic changes and human health;

- Noise of railway origin is less annoying than noise from other modes of transport; 
- In comparison with motor transport, railways require the smallest allocation of land based on a per ton-kilometer and passenger-kilometer (since the transportation land use is one of the impact indicators on the biological diversity of the planet);

- Minor cost of tickets and tourist services;

- Compliance with the balance between capacity and comfort in trains;

- Specifications of rolling stock design allow providing anti-epidemiological measures.

Over the past few decades, industry has undergone sustainable growth [7]. Since 2018 , the number of vehicles increased by 20,000 units, and the global railway network was extended to $23,300 \mathrm{~km}$. At the end of 2019, railway transport reached a record market value of EUR 177 billion, to a large extent thanks to investments in rolling stock, infrastructure, and railway control [8].

The COVID-19 coronavirus pandemic broke this by causing slackening in the rate of passenger and freight traffic. This led to the rescheduling and cancellation of orders, a significant decrease in the scope of services, etc. Despite these challenges, the attractiveness of the railway will quickly recover and continue its development $[9,10]$. The stability and demand of the industry give hope that there will be an average annual rate of growth until 2025 [8]. In addition, political initiatives, such as the European Green Deal, would continue to promote demand for "railroads" decisions. Due to ongoing efforts and thorough orientation to overcome obstacles, railway companies can hope for further development [11-13].

In the social sphere, railroads make a positive contribution to the implementation of the reliable mobility concept-high standards of safety of railway transportation allowed [14]:

- To save human life: many accidents and fatalities were avoided due to centralized control of railway transport;

- To create a space where people can meet and communicate (even in terms of the pandemics) while performing all sanitary requirements.

One of the active-popular components of transport is railway tourism that acts as an effective tool for expanding human life space and has an important cultural value. With quarantine restrictions, tourism (as well as other industries) has lost its positions in the service market. However, it should be noted that all pandemic and uncertain times will sooner or later end.

While organizing tourist transportation by railway, it is desirable for tourist operators to take into account external and internal risks [15]. Therefore, the purpose of the article is to develop multi-stage models of tourist activities to optimize the development of operating companies in the organization of railway tourism. This will help to determine the optimal (according to a certain criterion) group of routes and sequence of their putting into operation at a certain area. This will contribute to improving the moral, psychological, and financial position of all parties involved-the participants in tourist traffic.

Tourism is one of the fastest-developing and highly profitable branches of world economies. Railway tourism has recently become especially popular among different kinds of people who are partial towards traveling. It is assumed that traveling by railway has some definite advantages compared with other means of transport: possibilities to obtain services of "bed and meals", good environmental atmosphere, safety, relatively low fares, etc.

Nowadays, tourism is one of the fastest-developing, dynamic, and manifold branches of business all over the world. The profit of enterprises with tourist services has been growing [16]. Rail freightage is tightly connected with tourism, and in many cases rail freightage is multimodal.

Railways of many countries in the world use such service as railway tourism as a sustainable way to receive additional revenues. Travels by train attract both locals and foreigners. The railway excursions in old-fashioned cars on the narrow gauges are very popular. Among the successful railway tourist transportations are the following examples [17-19]. 
In the USA operates the Georgetown railway, a narrow-gauge line only $7.2 \mathrm{~km}$ long that ascends an elevation of $200 \mathrm{~m}$ above the sea level. For more than a century, it has been a very popular tourist attraction: a classic train with old-fashioned cars, powered by steam locomotive traction that carries passengers, gradually climbing the bridge of $30 \mathrm{~m}$ height. In India operates a narrow-gauge mountain railway Nilgiri with a length of $46 \mathrm{~km}$, connecting Mettupalayam and Udahanadalam. Another famous narrow-gauge railway in the world is the one on which passes the tourist train «Bernina Express», the route being Chur (Switzerland) to Tirano (Italy). The railway between Thailand and Burma or "Death Railway", which was built during the Second World War, is very popular with tourists. In Serbia, one offers for tourists twice-a-day train travel by "Nostalgia" at the $13 \mathrm{~km}$ narrow-gauge railway between the stations Mokra Gora and Sharhan Vitas. In Hungary, there are narrow-gauge railways in the cities of Palhaza, Miskolc, and Nyiregyhaza. They pass through the mountains and valleys, opening to tourists picturesque landscapes. In England at tourists' disposal is the smallest operating narrow-gauge railway in the world "Romney", with the gauge of only $381 \mathrm{~mm}$. The biggest narrow-gauge railway network is in Japan. In Argentina, the most famous among the tourists is the so-called "Train to the Clouds". During the travel, the train passes 29 bridges, 21 tunnels, and 13 viaducts.

The analysis of the literature on the theme allows us to state that railway transport is rational both from the point of view of safety and ecology of multimodal traveling. On the continent these kinds of transport are rather convenient and accessible as for the price parameters.

It should be mentioned that in the contemporary scientific literature the problems of formation and development of the tourist infrastructure have not been completely investigated yet. At the same time, formation of the new tourist routes which can be attractive for all the stakeholders (tourists, enterprises tourism businesses, and state) is a topical issue nowadays.

The main role for the development of tourist traffic on the railways play the following factors:

- The presence of existing infrastructure of railway tracks that is reconstructed or rebuilt and corresponds to the established standards of safety, motion speed, travel comfort, and is properly maintained.

- The presence of the developed tourist infrastructure around the railway.

- The presence of beautiful nature, places for active recreation, places for quiet rest, thermal waters for therapeutic tourism, resorts, local national characteristics, and nature reserves.

- The presence of tourists in local hotels that are potential clients of travel company.

- The presence of demand for these types of railway services from domestic and foreign tourists.

- The availability of modern comfortable rolling stock for different kinds of travel services depending on the travel period.

- Conducting efficient promotional campaign to attract the tourists to railway transportations.

- High level of tourist services during the train travel, accommodation in hotels and apartments, meals in restaurants and cafes, transfer and excursion services, high level of camps for active and quiet recreation, etc.

- The attractiveness of tourist routes to suit any taste, which make it possible to attract the maximum number of customers.

- Pricing and tariff policy of tourism companies and their contractors, which should take into account the cost of tourist services of the companies that use automobile transport for tourist transportations.

The final choice of tourist traffic should be justified by a methodological approach that is based on the principle of determining the actual number of passengers and revenues from tourist transportations on the certain routes and economic calculations. 
This article mainly concerns the problems of the railway usage as a basis for the development of the tourism potential in the regions. The following factors account for its significance. Firstly, from the historical point of view, railways have been forming and representing the most important social, trade, economic, and industrial links among the attractors, "appeal factors" of a region. Secondly, railway transportation is safe and reliable, convenient and comfortable ("a hotel on the rails"), and this means profitability and good environmental conditions. The combination of two mentioned components allows to consider the problems of the development and effective usage of the railway infrastructure as a basis for the growth of the regional tourist potential. The railway tourism, as a rule, operates internally, not internationally. However, in the contemporary conditions of globalization, the wide and long-term activity area can be created for the international railway transport and multimodal tourism. In our research the most attention is given to the railway transport; as for automobile transport, it is considered as a transfer means-carrying tourists from railways to the places of their interest.

The purpose of the article includes development and future elaboration of the model tourist potential of the region. This should be performed with regard for the formation of the tourist railway infrastructure. Being different from the known models, the contentmathematical models, proposed by us, are designed for the effective development of the tourist business on the basis of formation and application of the railway infrastructure. These models take into account several factors: first of all, some members of the project who are highly interested in it, then long-term period of the infrastructure project realization, and a lot of factors of uncertainty of different categories, which may be present in the project. As for the grounds for the planning models of tourism development, the following procedures are included: to determine interested parties in the project fulfillment and to establish models of their interaction at the different stages of the project realization; to form tourist routes with the bias on the "appeal factors"; to choose the succession of the "route" introduction (the present and future infrastructure, availability of the rolling stock, etc., are taken into consideration). This should be performed to maximize every party's planned profit from the tourist activity for an established period of time.

In our research the most attention is given to created economic-mathematical models of the discrete optimal planning of the railway tourism operations. This takes into account conditions of risks and cooperation, and allows to determine sets of effective routes which are most profitable ones, provided they meet the established demands. The latter includes routes which meet maximum criteria of the net costs under the conditions of the established system of demands for the activity of the tourism operators.

\section{Brief Literature Review}

Many scientific papers are devoted to the development issues of the tourist business.

Determining factors influencing the choice of a potential tourist to use any given service is a sufficiently relevant study.

A number of contemporary scientific publications are dedicated to the problems of studying and planning factors that influence tourists' preferences and their trips [20-23]. The role of "appeal factors" as essential components influencing the choice of tourists" routes is under the analysis in the paper [24]. Methods and means of providing tourism business growth in different regions, tourist's safety, ecological problems, etc., are also widely discussed in [25-30]. Here the importance of the factors of safety, comfort, entertainment, and such is marked, too. The issues of safety, and quality of police operation in particular, as one of the main components of the high service level, are represented in the paper [31]. In the article [32], the factors influencing both individual and collective population mobility are under analysis. The model proposed by the authors makes it possible to research migration regularities and to foresee volumes and directions of the traffic. In order to analyze the population mobility, the authors propose to use different-sometimes non-standard-ways (with the help of the trajectory of banknotes, mobile operators or GPS devices). The model developed in means constructing a set of streams of tourists' trips 
with the restrictions of different kinds taken into account. It is stated that people's trips are not accidental, and in most cases can be easily predicted.

We would like to focus on the fact that tourist and transport services go hand in hand because while traveling, consumers use one or another mode of transport. Therefore, the availability of tourist infrastructure from the viewpoint of transport accessibility is a rather important aspect for choosing a tourist in favor of one or another tourist journey. In the paper [32], the authors also argue that integrating transportation accessibility factors into CGE models will be a crucial factor in future research to properly assess the impact of transportation on tourism. In the paper [33], the direct dependence is established between the aim of a trip and variants of its realization. The model of the event-oriented simulation is represented which takes into account factors of uncertainty and permits to satisfy the maximum client's demand for the tourist services. At this, the traveling conditions and accommodation, the number of places of interest, travel fares, ways of payment, and other factors are taken into account.

Positive examples of organizing tourist traffic by railways in different countries of the world presented in the Introduction section and the studies of respected scholars point toward the attractiveness of railways as a vehicle during a tourist trip, and sometimes as an independent tourist service (after all, the train can be used as a means of moving, overnight, food. During specially organized stops, tourists can reach places of cultural-historical or other significance by road or water and return to the tourist train again). For example, in [34] the authors highlight a close interaction between the cultural-historical heritage, the presence of railways, and, accordingly, the demand from tourists for traveling to these places. Moderate fare costs, the novelty of impressions, provision of new services in the trains, safety and comfort typical of railway tourism, are in the focus of attention in the article [35]. In the article [36], passenger transport by railway is regarded not only as a business but also as a social function. In order to evaluate the relations of passenger transport by railway and the macroeconomic processes of a country or region, the macroeconomic social turnover indicators, that characterize the passenger transport activity, are chosen, and the methods of economic statistical analysis are used. The interconnection of passenger railway transport's indicators and Lithuania's macroeconomic indicators are measured by calculation. The topic of interoperability installation in the Lithuanian railways is presented as well, and the benefits and costs of activities of the main stakeholders in railway transportation are projected.

The planning model of the best tourist routes with the use of rail transport, from the viewpoint of all stakeholders, is determined in the article [37]. A realistic road-rail intermodal transport system can be suitably modeled as a hub-and-spoke (H\&S) network for which the parameters are subject to fuzzy uncertainty: demand, cost and time [38]. We find research [39] on the competitiveness of the use of railways. TIMES-DKEMS is a novel methodology [39] paving the way for applying elasticities of substitution to incorporate transport modal shift into TIMES (The Integrated MARKAL-EFOM System) models. Substitution elasticities are defined for four transport demand aggregates, each corresponding to a different distance range class. Within an aggregate, modal demands can adjust their levels according to the defined substitution elasticity and in response to changes of their shadow prices relative to a reference case. Results show that in 2050, 11\% of car mobility demand will be substituted by more efficient and less costly modes such as train and coach.

Unfortunately, now many railways are closed due to a smaller passenger volume and, as a consequence, unprofitability $[40,41]$. The problem of the future of abandoned railways is of great importance [42]. In the article [43,44], options for using railways are studied with the conclusion that one of the best solutions is their re-equipment in the "green zones". However, we believe that the existing railways are desirable not to close, but to reconstruct.

It should be noted that developed transport infrastructure is not always near the tourist infrastructure. Here there may be a question for investors regarding whether or not to invest in the development of traffic infrastructure and the purchase of new tourist rolling 
stock. To solve this task, some scholars conducted a comprehensive study. The paper [45] presents a mathematic model elaborated to determine expedient investor's shares and probable profits which may be earned from projects associated with improvements of road traffic safety. The paper [46] is the first to study to what extent decision rules, embedded in disaggregate discrete choice models, matter for large-scale aggregate level mobility forecasts. Such large-scale forecasts are a crucial underpinning for many transport infrastructure investment decisions. Authors show, in the particular context of (linear-additive) utility maximization (RUM) and regret minimization (RRM) rules, that the decision rule matters for aggregate level mobility forecasts. They find non-trivial differences between the RUM-based and RRM-based transport model in terms of aggregate forecasts of passenger kilometers, demand elasticities, and monetary benefits of transport policies.

The analysis of the literature on the theme allows us to state that interaction of railway and automobile transport is rational from the point of view of both safety and ecology of multimodal traveling. On the continent these kinds of transport are rather convenient and accessible as for the price parameters.

It should be mentioned that, in the contemporary scientific literature, the problems of formation and development of the tourist infrastructure have not been completely investigated yet. At the same time, formation of the new tourist routes which can be attractive for all the stakeholders (tourists, enterprises tourism businesses, and state) is a topical issue nowadays [47,48].

Having analyzed about 600 tourists railway routes all over the world, we have stated the following [49]:

(1) Tourism is a way to expand people's outlook and life space, as it improves one's moral state, being a kind of "antidepressant";

(2) For tourists the priority is with the travel safety, then tour fares, the service level, trip duration, and others;

(3) The popularity of tourist trains does not depend on the width of the gauge;

(4) Both relatively cheap short-term trips, which cost several hundred US dollars, and long-term elite tours, which cost about twenty thousand US dollars, are in demand nowadays;

(5) Tourists are inclined to visit more advertised tourist objects.

Considering the fact of the popularity of railway tourist routes in the world, we consider that it is expedient to develop this kind of travel in countries where the tourist and transport (railway) infrastructures operate or they are advanced, or there is an opportunity to develop/build them. We believe that recommendations proposed by us in this study (in the form of economic-mathematical models for planning tourist routes by railway) are sufficiently relevant for all stakeholders of railway tourism-owners of railways, passengers, investors, and other involved persons and organizations [50].

We believe that, firstly, a group of scholars in a country that are interested in the implementation of railway tourism should conduct comprehensive research on the development of tourist and transport industries. In this case, it is necessary to make a revision of all existing railway networks with the definition of its serviceability to organize railway travel. Next, one needs to analyze possible potentially interesting places for visiting by tourists. Next, it is necessary to analyze the statistics of visiting the chosen places of tourist leisure, to determine whether it is possible with the help of side events-the development of transport/tourist infrastructure to increase the demand of potential tourists exactly to these places of rest. It is also necessary to evolve a plan concerning the active advertising products in social networks and other modern popular types of agitation and consumer motivation to choose one or another type of product or service (in our case it is a railway journey). Further, researchers should check the availability and quality of rolling stock, determine how many cars or trains are suitable for the organization of tourist transportation. In the absence of an adequate number of tourist cars/trains, it is necessary to propose measures to purchase them or their self-design projects. Based on the analysis of tourist and transport infrastructure and tourist attraction zones to specific places, one needs to 
plan several, from 5 to 15 , potentially possible tourist routes. Then, one should apply the model developed by the authors of this article to determine the priority in launching tourist routes; since starting them simultaneously is a sufficiently cash-consuming project, it can be immediately uninteresting for potential investors, because the payback period may be too long (Figure 1).

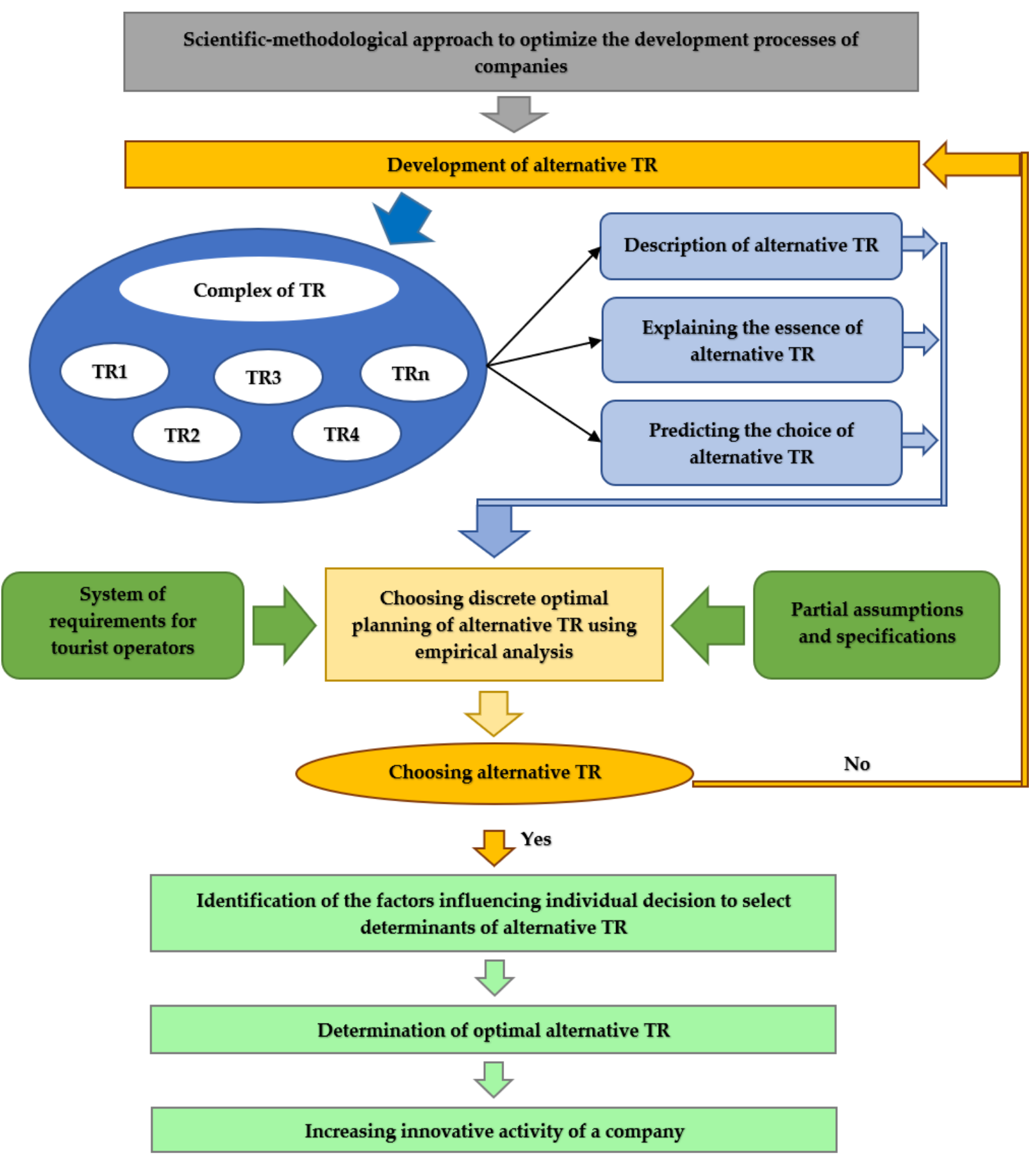

Figure 1. The organizational-functional mechanism to support the operation of companies.

Railway tourism is a complex of socio-economic relations, combining a wide range of types of industrial and economic activities that are related to the movement of tourists, providing them with the necessary service and full range of services during a trip (transport and infrastructure; hotel and entertainment complex; food industries, etc.) [51,52]. 
Considering the growing desire of members of society to expand their worldview by traveling, it is meaningful to introduce railway tourism [53]. Thanks to the attractiveness, reliability, and eco-friendly characteristics of railway transport and its infrastructure, such trips can provide (compared to other modes of transport) [54-57]:

- An environmentally friendly way for the movement of tourists that does not depend on weather conditions;

- High-quality comfort during movement, since rail cars have enough space for passengers and luggage in compliance with quarantine norms;

- Physical activity for some groups of people (children, people with disabilities, and elderly age) with the implementation of sanitary requirements during pandemics and cataclysms;

- Affordable pricing policy of traveling by tourist train (with the overnight stays).

All these advantages of railway tourism acquire special relevance in uncertain times. Though railway tourism transportation has its own specifics, at the same time, the availability of railway communication is one of the factors that motivate tourists to travel. An adjusted connection between tourist and transport infrastructures is needed to increase the volume of tourist traffic [58,59]. Therefore, for high-quality work, a company dealing with the organization of railway tourism trips should have clear objectives, specific tasks, competent personnel, modern technologies, a perfect organizational structure of management, and finance. Simultaneously, the company will not be able to operate without customers, investors, and suppliers of various resources [60].

In light of these requirements, the authors have formulated an appropriate system of organizational and functional support for the development of railway tourism. It is endowed with properties and grounded on the principles given in Figure 1.

The essence of the proposed system is to construct a hierarchical structure and verification of specific properties in the system to ensure the effective development of the operating company [61]. The scientific-methodological approach in organizing railway tourism (Figure 2) is based on the use of a description, explaining, and predicting with the help of discrete optimal planning to define the alternative tourist routes (TR) [62]. Therefore, it is necessary to have information concerning the rolling stock, the number of tourists and routes of a tourist train, the number of stops for excursions, nutritional conditions, overnight stays, etc. [63].

In our opinion, a system for ensuring successful operation of companies that will organize rail trips should be based on following principles (Figure 2):

- "Scientificity" - the need to apply scientific methods for assessing the level of innovative development, prospects for its increase, the level of the company's innovative potential, processing the information obtained, an analysis of investigated trends in the development and predictive scenario for the short-term, and strategic perspective;

- "Integration" - mutually casual and proportionally mutually agreed development of system as a single whole, which ensures the connection of all subsystems and elements;

- "Economic expediency" — cost of measures in a system's operation for ensuring that the successful functioning of companies that will organize rail trips should not exceed the cost of received economic results from the project realization on the implementation of railway tourism;

- "Multivariation when making the managerial decisions"- the development and analysis of various approaches towards the achievement of the set target points;

- "Scope" - possibility to attract both internal resources of the enterprise (personnel, finance, ideas), and external ones (consultants, loans, venture capital, etc.);

- "Orientation for the consumer of transportation services" - those innovations (external), which are aimed at improving quality of transport services and thus increasing the level of satisfaction of tourists, have the priority in the development process compared to those aimed at improving the organizational structure, as well as methods of calculating indicators (internal) that do not attract the consumer attention; 
- "Systematicity" - the system has to be considered as a subsystem of a more complex system, within which the travel company operates; maybe it will be a passenger sector of the great railway;

- "Supply of necessary resources"-financial, informational, material, labor.

For the successful service management of the company, which will organize the tourist rail transport, one needs to use the appropriate organizational and functional support. These include both material and intangible components of ensuring the operation of this company.

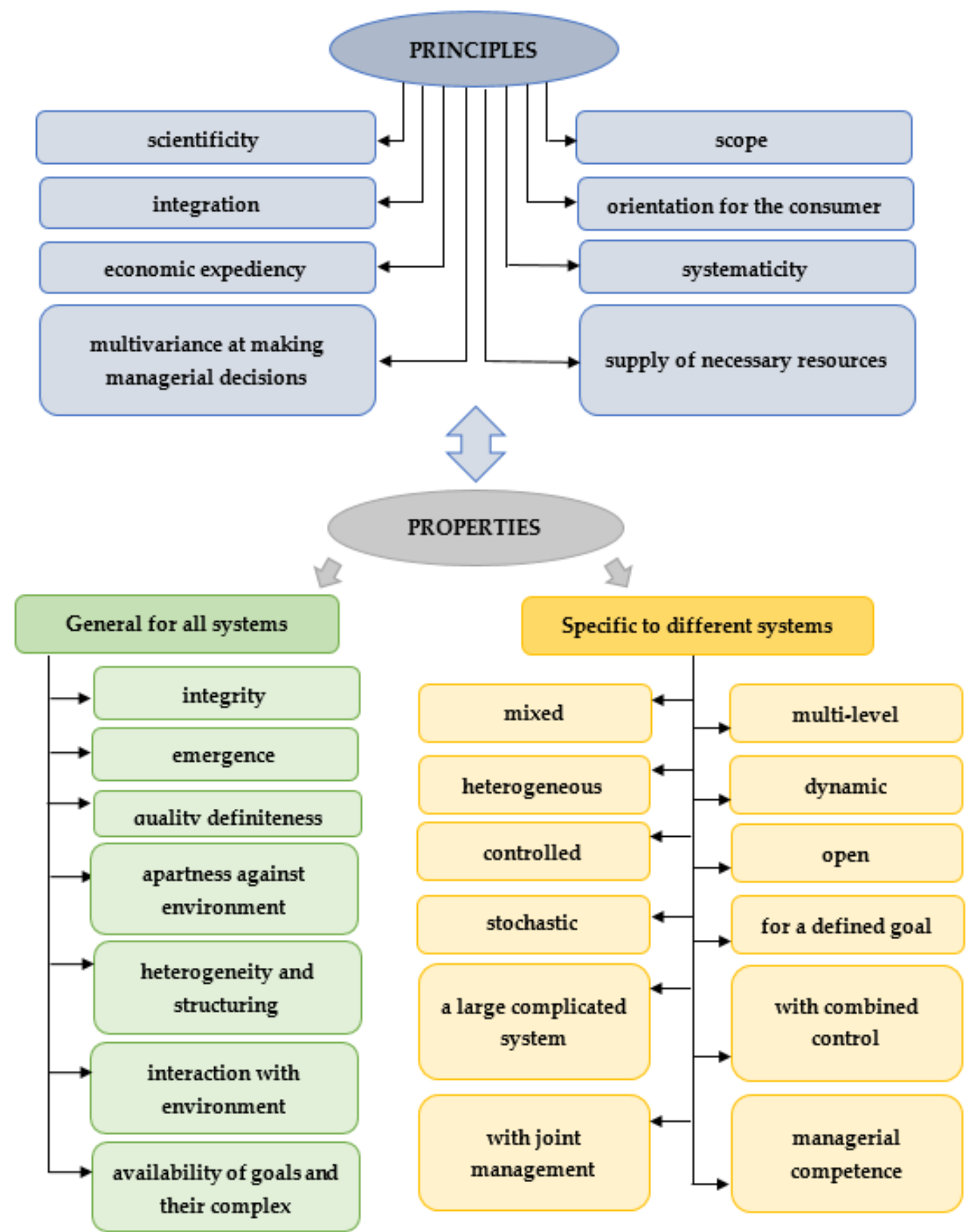

Figure 2. The organizational-functional mechanism to support the operation of companies. 
Figure 2 presents specific properties and principles which have to be at the basis (according to the authors' opinion) for the formation and operation of companies.

In the theory of a system, there are following main features, common for all systems: "integrity"; "emergency" (the emergence of new qualities that are not characteristic of the elements that make up a system); "qualitative definition" (a system has its qualitative features that are characteristic of this system and are absent in other systems); "isolation relative to the environment"; "heterogeneity and structuredness"; "interaction with the environment"; and "availability of goals and their complex".

In addition to those, we believe that the structure of the company organizing rail trips has its own, specific properties, namely, they are as follows:

- "Mixed" - by nature of elements (both wildlife-people and inanimate nature-fixed assets, material values, etc.);

- "Heterogeneous" - since the elements that are part of a system (objects, agents, products, etc.) are different in nature and properties;

- "Controlled" - a system is subject to the focused impact of control bodies of different levels for its effective functioning;

- "Stochastic" —after all, it, like all other socio-economic systems, is not subject to exact prediction;

- "A large complex system"-because it consists of many subsystems. They are divided into many elements with the presence of complex interdependencies between them [64];

- "With joint management"-a system for ensuring the successful functioning of companies that will organize rail trips, contains both elements created by a person (part of fixed assets, working capital, etc.) and elements of natural origin (people-personnel);

- $\quad$ "Multi-level" — a system may have several levels of management (at the level of the company's top management and departments), and in the structure-it consists of several subsystems, and those in turn-from elements;

- "Dynamic" - significant changes in time will be in the process of organizing railway tourism (in the structure of management, functioning efficiency, etc.);

- "Open" - entry of substances, energy, and information from the external environment change a system;

- "For a defined goal" - since the system for ensuring the successful functioning of companies is created and operates for a defined goal, namely, the implementation of railway tourism;

- "With combined control"-automatic, semiautomatic, automated, organizational management structures;

- "Managerial competency".

Thus, in Figure 2, specific properties and principles have been formulated based on the synthesis of process and stakeholder approaches using the conceptual apparatus of the theory of systems. According to the authors' opinion, the formation and functioning of companies that will organize rail touristic trips should be based on them.

\section{Research Methodology}

The companies which determine their strategic plan with aim toward the opening of certain tourist routes using railway rolling stock, are developing and implementing anti-crisis measures. Among these are large-scale planning with regard to potential internal and external risks and threats that can be distinguished [65,66].

On the basis of the latter, the authors developed multi-stage economic and mathematical models that will allow operating companies to assess risks when planning tourist routes by railway, to determine the order of construction or starting routes, and to assess the profitability of tourist routes (TR).

While developing multi-stage planning of models, the railway tourist routes are regarded as specified. Let us consider possible variants of decisions depending on the type of initial information. The authors approved the following: conditional variants of 
tourist routes (TR) at the railway area are marked with a letter " $\mathrm{N}$ ". For consideration, five conditional TR are admitted, which are distinguished by duration and comfort.

All routes are presented in such a way that it would be possible to compare their profitability per year. Restrictions on traction and rolling stock are common for all variants of alternative routes.

The task of optimal planning is to define such variable values that meet models' restrictions and provide maximum profitability. The results by appropriate variants are:

- $\quad \mathrm{N} 1$ is one TR;

- $\quad \mathrm{N} 2$ is one TR, but taking into account risks;

- $\quad \mathrm{N} 3$ is a group of TR, which together meet restrictions on available resources;

- N4 is a group of TR, which together meet restrictions on available resources taking into account risks;

- $\quad \mathrm{N} 5$ is the co-operation of TR, which provides maximum profitability when combining routes.

For all variants, one should define descriptions of individual routes, each of which is presented in models by a separate binary variable. The permissible values of variables and tolerance region of production and economic indicators are established.

We offer models and algorithms for optimal planning of tourism activity, considering risk conditions. Let us consider the formation of structures and model components in planning according to N1-N5 variants. To do this, a model for the variant of N1 planning is defined. On its basis, other N2-N5 settings are formed further. In the conditions of the existence of certain variants for tourist routes $M_{i}, \quad i \in M I$ any implementation of optimal plans is to calculate numbers or indices of some subset of routes MI. Let us denote binary variables that correspond some route with $x_{i} \in\{0,1\},(i=\overline{1, m})$, where: $m=$ the total number of tourist routes, and the value $x_{i}=1$ means a decision on the inclusion of the route to the optimal plan. The general vector in problem solutions of planning has the form:

$$
\bar{X}=\left(x_{1}, x_{2}, \ldots, x_{m}\right)
$$

In order to establish the connection of the railway network and realizing the capability for tourist routes service with the same traction rolling stock we introduce a connectivity matrix:

$$
C X=\left[c_{i j}\right] m \times m
$$

where $c_{i j}=1$ if railway routes are linked, $c_{i j}=0$ if they are not linked.

For all TR, variants in organizing tourist railway transportation are formed separately. On each route, we will consider various variants for organizing tourist railway transportation $z_{i}$ (they differ in the travel time and level of comfort). Let us denote:

$$
z_{i k} \in Z_{i}, i \in M I
$$

In the next stage, we analogically denote calculations of the cost of opening various versions of tourist service:

$$
s_{i k} \in S_{i}, i \in M I
$$

Matrices $z_{i}$ and $S_{i}$ define in the model the activities of tourism operators on the route $M_{i}, i \in M I$. In order to form a general model of tourist activities, one needs to enter the objective function. The optimal planning task will be:

$$
\left\{W(\bar{X})=R_{i}(\bar{X})\right\} \Rightarrow \max _{X \in G_{x}}
$$

where $G_{x}$ is the tolerance region of the parameters of plans defined on the base $\bar{X}(1) ; R_{i}(\bar{X})$ corresponds to the optimality indicator of N1 variant, $W(\bar{X})$ corresponds to any other model of optimal planning. A set of constraints $G_{x}$ consists of the following components in the organizing tourist railway transportation: 


$$
\begin{gathered}
G_{k}(\bar{X}) \leq 0, \quad k \in\{T, V, C, t, I, P\} \\
x_{i} \in\{0,1\},(i=\overline{1, m}) ; N_{X}=2^{m}
\end{gathered}
$$

where:

$G_{T}(\bar{X})$-availability of a traction rolling stock;

$G_{V}(\bar{X})$-availability of a passenger rolling stock;

$G_{C}(\bar{X})$-coherence of routes;

$G_{t}(\bar{X})$-restrictions on the travel time;

$G_{I}(\bar{X})$-availability of infrastructure;

$G_{P}(\bar{X})$-investment restrictions.

The investment economic-mathematical model [67] of optimal planning of development of railway tourism as a choice of one route from set $M_{i}, \quad i \in M I$, and the best on the indicators of net present value are defined by Ratios (1)-(7). Equation (7) indicates the number of possible variants of plans among which optimal on the criterion is selected (5). Through the selection of variables (1), the model of multi-stage planning of tourist activities is a model of discrete mathematical programming, considering (7) it can be implemented by the brute-force search. At the same time, it is necessary to take into consideration the variants of settings, in which groups of routes are determined and ordered regarding their readiness, as well as the availability of investments. In order to form an algorithm of numerical implementation (1), (5)-(7), we present the structure of an individual route in this form:

$$
S t_{i}\left[M_{i}, R w_{i}, \ell_{i}, T_{i}, S P_{i}(t), Z_{i}, S_{i}, R T u r_{i}\right]
$$

where:

$M_{i}$ - a tourist route identifier (TR);

$R w_{i}-\mathrm{a}$ list of railway nodes belonging to a specific TR;

$\ell_{i}$-TR length;

$T_{i}$ - TR travel time;

$S P_{i}(t)$-amount of expenses for the opening of TR for period $t$;

$z_{i}$-implementation variations respectively (3);

$S_{i}$ - the estimated costs of tourist service variants in accordance with (4);

RTur $_{i}$ - the expected number of tourists on a particular TR.

The algorithm for implementing the model (1), (5)-(7) is as follows:

1. To set the initial values of variables and assessment of the objective function

$$
\bar{X}(0)=\left(x_{1}=0, x_{2}=0, \ldots, x_{m}=0\right) ; R_{1 *}(\bar{X})=R_{1 \text { min }} ; \bar{X}_{o p t}=\bar{X}(0)
$$

2. To set the initial counter value of variants $C N_{x}=0$. The binary representation of the number $C N_{x}$ gives a variant to implement a tourist activity plan $x_{i} \in\{0,1\},(i=\overline{1, m})$

3. To finish the optimization procedure. In case $C N_{x}+1$ is larger than $N_{x}=2^{m}$, go to point 9.

4. To form the current vector of activity variants $\bar{X}(C N)$, in which value $x_{i}=1$ indicates the inclusion of the route to the plan.

5. To set for each $x_{i}=1$ a counter of variants number for realizing $z_{i k}$ with matrices $z_{i}$, $z_{i k} \in Z_{i}$.

6. To calculate the model indicators (5)-(7).

7. To check the system of restrictions (6). If conditions are not met, then return to point 3.

8. To perform a comparison of the preliminary value of the objective function $R_{1 *}(\bar{X})$ with current $R_{1}(\bar{X})$. At $<R_{1 *}(\bar{X}) \leq R_{1}(\bar{X})$ to change $R_{1 *}(\bar{X})$ for $R_{1}(\bar{X})$, to remember $\bar{X}_{o p t}=\bar{X}$. Go to point 3 .

9. To obtain results of optimal planning $\left\{\bar{X}_{o p t} ; R_{1 *}\left(\bar{X}_{o p t}\right)\right\}$.

Choosing a group of optimal tourist routes on condition of risks (variants for N3, N4 settings) can be implemented if the system of restrictions is performed simultaneously for 
all selected routes. Meaningfully, such a decision is possible when providing the coherence of routes, the sufficiency of rolling stock units, the readiness of the infrastructure, and the like. The main forms of criteria in the deterministic case N3 are:

$$
\left\{W(\bar{X})=\sum_{k} R_{k}(\bar{X})\right\} \Rightarrow \max _{X \in G_{x}}
$$

On condition of risk N4:

$$
\left\{W(\bar{X})=\sum_{k} R_{k},(\bar{X})+M\left[f_{k n}(\bar{X}, Y(\bar{X}, \theta), \theta)\right]\right\} \Rightarrow \max _{X \in G_{x}}
$$

With index «k» we designate the route numbers, which together are included in the group of optimal; $\theta=\theta_{1}, \theta_{2}, \ldots, \theta_{s}$-sets of random states that define a certain predictable scenario of implementing the failure (changes in the processes of track development, purchasing of rolling stock units, lack of timely investment support, etc.). Other designations of planning models (9)-(10) keep those previously established. Models of co-operation of routes to provide a maximum of total profitability when they are combined differ by the definition of the trips implementation frequency on each route that has been included to the optimal group. In them, unlike settings (9)-(10), the frequencies of trips implementation are calculated for which maximum profitability is ensured. Implementation of these requirements may be represented by efficiency criteria of the following tasks of optimal planning:

$$
\begin{gathered}
\left\{W(\bar{X})=\sum_{k} v\left(\theta_{k}\right) R_{k},(\bar{X})\right\} \Rightarrow \max _{X \in G_{x}} ; \sum_{i} v\left(\theta_{i}\right)=1 \\
\left\{W(\bar{X})=\sum_{k} v_{k}\left(R_{k}(\bar{X})+M\left[f_{k n}(\bar{X}, Y(\bar{X}, \theta), \theta)\right]\right)\right\} \Rightarrow \max _{X \in G_{x}}
\end{gathered}
$$

The condition of standardization $\sum_{i} v\left(\theta_{i}\right)=1$ is used for variants of routes from (1), which were included to the optimal plan $\bar{X}_{\text {opt }}$. The objective function determining the rate of the net present value (NPV), is as follows:

$$
N P V=\sum_{t=0}^{T} \frac{\sum\left(L_{t}-B_{t}\right)\left(1-\frac{\gamma}{100}\right)+A_{t} \frac{\gamma}{100}-K_{t}}{\left(1+E_{m}\right)^{t}}+R \rightarrow \max
$$

where:

$L_{t}$ annual income;

$B_{t}$ annual costs;

$\gamma$ income tax, \%;

$A_{t} \quad$ depreciation payments;

$K_{t} \quad$ annual investments;

$t$ a number of a target year, $t=0,1,2, \ldots, T$;

$R$ reversion;

$E_{m}$ real discount rate.

The authors suggest that the general criterion (5) of an optimal planning model takes a specific form (13), and the calculation parameters and restrictions are given below. While forming an algorithm for implementing a model of discrete optimization, we propose the following:

- The performance of the independence principle of indicators on individual tourist routes, that allow constructing the additive calculation models;

- Carrying out of requirements in the coherence of routes on the entire railway polygon. 
We will consider the introduction of each railway route as a project- $P r_{i}(t)$. In order to establish optimal priority at the start of tourist routes, we form the next matrix of economic expediency of productive activity at stages:

$$
E(\operatorname{Pr} t)=|e(i, t)|
$$

where elements $e(i, t)$ determine the effectiveness of projects by Formula (8) in relation to routes $M_{i}$ if they begin in period $t$. It should be noted that in Matrix (14) all elements $e(i, t)$ are calculated based on the number of implementation variants $z_{i k}$ by matrices $z_{i}, z_{i k} \in Z_{i}$. That is, the best assessments of the characteristics in the phasing introduction of TR to the plan are maintained. According to the independence principle of routes, the matrix can be arranged by reducing the efficiency index $e(i, t)$. The effectiveness matrix for TR ordering in the future is applied to form optimal variants of implementing a multi-stage investment model for planning the railway tourism development. The phase of routes or routes groups is set by the indicator of period $t$.

\section{Results}

Summary algorithm for implementing the model (1)-(14) for setting N1 variant is as follows:

1. To set the initial values of variables and objective function assessment $\bar{X}(0)=$ $\left(x_{1}=0, x_{2}=0, \ldots, x_{m}=0\right) ; N P V_{1 *}(\bar{X})=N P V_{1 \min } ; \bar{X}_{o p t}=\bar{X}(0)$.

2. To set the initial counter value for variants $C N_{x}=0$. Note that the binary representation of number $C N_{x}$ gives a variant for implementing the tourist activity plan $x_{i} \in\{0,1\},(i=\overline{1, m})$.

3. To generate next variant $C N_{x}+1$. In case $C N_{x}+1$ is larger than $N_{x}=m$, finish the optimization procedure and go to point 9.

4. To form on the base of $C N_{x}$ the current vector for variants of activity $\bar{X}(C N)$, where the value $x_{i}=1$ indicates the inclusion of the route to the current plan.

5. To set for each $x_{i}=1$ a counter of variants number for implementation $z_{i k}$ by matrices $z_{i}, z_{i k} \in Z_{i}$.

6. To calculate the model indicators (5)-(14).

7. To check the system of restrictions (6). In case of failure to meet the requirements, go to point 3.

8. To perform the comparing values of objective function $N P V_{1 *}(\bar{X})$ with current $N P V_{1}(\bar{X})$. At $<N P V_{1 *}(\bar{X}) \leq N P V_{1}(\bar{X})$ to replace $N P V_{1 *}(\bar{X})$ by $N P V_{1}(\bar{X})$, to remember $\bar{X}_{o p t}=\bar{X}$. Go to point 3 .

9. To obtain the result of optimal planning $\left\{\bar{X}_{o p t} ; N P V_{1 *}\left(\bar{X}_{o p t}\right)\right\}$.

The above-mentioned algorithm is suitable for calculating the models of all settings.

Meaningfully, a simplified algorithm for N1 is as follows:

- $\quad$ For the selected route $M_{i}$ in Matrix (14) from the ordering, the first element is selected $e(i, t)$, for which conditions of the acceptable decision are fulfilled (6);

- Indicator (13) obtained for it is compared with similar indicators of other TR according to point 8.

In the group formulation of tasks, the general algorithm remains, but the multiplicity of group elements of optimal routes is taken into consideration. Namely:

- For those generated in accordance with points 3 and 4, a TR group is determined to verify the admissibility by (6) and effectiveness by (13);

- For each route project $\operatorname{Pr}_{i}(t)$ that has been included to the group of a generated variant, the best variants by effectiveness are selected from Matrix (14);

- For the variants selected at the previous stage, the conditions of acceptable decision (13) are checked (13); 
- In case of performing the constraint system, go to point 8. If a variant is unacceptablefor TR group in (14) the following by efficiency implementation from TR group is defined.

Due to the limited number of routes, as well as preliminary ordering, the optimal decision will be calculated by the final number of iterations. Let us develop models of choosing alternative tourist routes, considering the conditions of risk and co-operation. To do this, we will consider the task of planning and selecting the introduction of TR with regard to random states $\theta=\theta_{1}, \theta_{2}, \ldots, \theta_{s}$. Such planning models under risk conditions arise when probabilities (or subjective probabilities) of possible state perturbations or system parameters are known [34]. When modeling models in this case, we define the scenarios of failures $V_{k}$ for each possible change, that will be described by a separate template $S_{k}\left(V_{k}, H_{k}, P_{k}\right)$. When modeling the optimal planning, we determine the value of the characteristic parameters of the conditions of uncertainty $\theta$, as well as for assessment of additional costs $\mathrm{Hi}$ required to compensate the changes $P_{k}$. In doing so, values $\left\{P\left(\theta_{i}\right)\right\}_{s}$ are set by expertise. Let us define states $\theta$ of changes as ranges $\left[d_{i}^{1}, d_{i}^{2}\right]$ in values of some deviations of total target figures.

$$
\theta_{i}=\left\langle\left[d_{i}^{1}, d_{i}^{2}\right], h_{i}\left(\theta_{i}\right), p\left(\theta_{i}\right)\right\rangle ; \sum_{i} p\left(\theta_{i}\right)=1,
$$

where $h_{i}\left(\theta_{i}\right)$-specific assessments of additional costs for the plan revision under conditions $\theta_{i}$. Description of random parameters of models, as well as functions of additional costs, formalizes the position of two-stage models in the planning of railway tourism processes. The result of research data is a generalized two-stage planning model that has the form:

$$
\left\{W(\bar{X})=N P V_{1}(\bar{X})+M\left[f_{h}(\bar{X}, Y(\bar{X}, \theta), \theta)\right]\right\} \Rightarrow \max _{X \in G_{x}}
$$

where $N P V_{1}(\bar{X})$ is a determinated function, this is a cost estimate of the planning vector when performing deterministic planning conditions;

- $\quad f_{h}$ - the function of additional costs necessary for the plan implementation in conditions $\theta, Y\left(X^{(t)}, \theta\right)$;

- $\quad M$-expectation sign.

In implementation (16) using the methods of stochastic programming for some $X^{\prime} \in$ $G_{x}$ and for each $\theta_{i} \in \theta$, we calculate and summarize with $p\left(\theta_{i}\right)$ value $f_{h}\left(X^{\prime}, Y^{\prime}, \theta_{i}\right)$, that together with NPV $(X)$ give the assessment $X^{\prime}: W\left(X^{\prime}\right)$, that measures quality $X^{\prime} \in G_{x}$ within two-stage planning (16). In accordance with (16), the optimal decision $\bar{X}_{\text {opt* }}$ provides a maximum of a net present value rate under conditions of expected additional costs in the occurrence of changes (15) when organizing tourist rail transportations. Other components of the model and the algorithm for implementing N2 formulation correspond to (1), (5)(14). The criterion (16) summarizes models of choosing the group of optimal TR under conditions of risks and in the cooperation of routes. Choosing the group of optimal TR in deterministic parameters or under conditions of risks can be implemented if the system of restrictions is performed simultaneously for all selected routes. Due to the fact that settings and models of analysis and ordering of groups of railway routes are formed by simple combining of all activity variants, as well as restrictions for resources, the forms of criteria in a deterministic case $\mathrm{N} 3$ are:

$$
\left\{W(\bar{X})=\sum_{k} N P V_{k}(\bar{X})\right\} \Rightarrow \max _{X \in G_{x}}
$$

Under conditions of risk N4:

$$
\left\{W(\bar{X})=\sum_{k} N P V_{k}(\bar{X})+M\left[f_{k h}(\bar{X}, Y(\bar{X}, \theta), \theta)\right]\right\} \Rightarrow \max _{X \in G_{x}}
$$


The designation of planning models (17)-(18) keep those previously established. Models of co-operation of routes to provide a maximum of the total net value vary from models of criteria (18)-(19) by travel frequencies for each of TR, which were included in the optimal group. In these, the frequencies of trips are calculated for which the maximum total level of indicator is provided $N P V_{*}(\bar{X})$. The model can be applied to implement such additional requirements:

$$
\left\{\begin{array}{l}
\left\{W(\bar{X})=\sum_{k} N P V_{k}(\bar{X})+M\left[f_{k h}(\bar{X}, Y(\bar{X}, \theta), \theta)\right]\right\} \Rightarrow \max _{X \in G_{x}} \\
\sum_{i} v\left(\theta_{i}\right)=1
\end{array}\right.
$$

Standardization condition $\sum_{i} v\left(\theta_{i}\right)=1$ corresponds to those variants of tourist routes from the variable vector (1), which were included in the optimal plan $\bar{X}_{\text {opt }}$. To calculate the optimal frequency values $\sum_{i} v\left(\theta_{i}\right)=1$, with which it is necessary to select individual routes in an optimal cooperative plan $\bar{X}_{\text {opt }}$ (in order to ensure the requirements for the acceptable decisions (6)-(7)), the task of linear programming is formed in relation to the number of performance of individual routes. The above models of planning of railway tourism development are formed based on the existence of a single investment center (the maximum profitability was as a criterion of optimality). At the initial stage, the organization of railway tourism is fairly a financial cost investment project. For opening tourist routes, one needs to repair or build a new transport and tourist infrastructure, buy a modern rolling stock, and envisage providing the transfer service for tourists with other modes of transport during a railway trip. Such a large-scale project is easier to launch for the investor group who can separately be responsible for their segment of organizing tourist railway transportation. If investors have a conflict of interest regarding the distribution of incomes from tourist activities, it is necessary to develop an appropriate economic-mathematical model.

In this case, the authors offer to apply the following model:

$$
F_{c}(V)=\max _{V}\left[\theta=\min _{k}\left(\frac{V_{k}}{D_{k}}\right)\right]=\theta_{c}
$$

where:

$V_{k} \quad$ profit margin of k-th investor;

$D_{k} \quad$ investment volume of k-th investor.

The presented model takes into account the interests of investors, depending on their financial contribution to the opening of railway tourist routes.

\section{Multi-Criteria Multi-Stage Planning}

The given planning models of the railway tourism regional development are formed provided there are definite conditions of interests of the united investment center. That is why the maximum values of the total income are represented as optimum criteria. The models mentioned above do not envisage participation in the project and competition with several investors $(\mathrm{UH}(\mathrm{K}))$ who are interested in the urgent development of the different tourism routes. We are to consider briefly some problems of formalization of the competition mechanisms and their efficiency analysis. First of all, the given criteria are based on the rule of the external solution of the conflicts among $\mathrm{UH}(\mathrm{K})$. In this case, the mechanism of the redistribution of the obtained maximum income is established outside the planning model. The creation and realization of such a mechanism is connected with the solution of many non-formal problems, which are not discussed in this paper. The game principle of the guaranteed result is offered to be used as a method of conflict solution $\mathrm{UH}(\mathrm{K})$, which realize the demand of the equality of the infrastructure investors

$$
F_{C}(V)=\max _{V}\left(\theta=\min _{V}\left(\frac{V_{k}}{D_{k}}\right)\right)=\theta_{C}
$$


where $V$-is a value of K-investor's income, and $D_{k}$-the volume of their investment. The realization of the planning model with the criteria (21) permits to choose tourists routes and the trip frequencies which provide income $\mathrm{UH}(\mathrm{K})$ corresponding to their contribution in the project of the railway tourism development. We are to analyze the numerical realization of the calculation algorithm of the choice of the tourism routes variants in the conventional example (Tables 1-9).

The example of the calculation of income in the tourism routes variants.

For economic justification of building new or reconstructing the existing narrow-gauge railways in order to transport tourists, one should determine the amount of future tourist routes, their duration, the number of journeys and the structure of rolling stock during the year and the presence of tourist infrastructure and historical monuments in the district served by the narrow-gauge railway.

The article proposes a methodological approach that is based on the principle of determining the actual number of passengers and revenues from tourist transportations on the certain routes. Taken into account are the attractiveness of the route, price for tourist vouchers or travel tickets, minimization of the rolling stock number, and the cost of construction and income of the company. Table 1 represents the real data concerning the development of tourism and recreation in the Transcarpathian region for 2015. It should be said that they are greatly underestimated because they do not take into account a significant share of tourists staying in the apartments.

Table 1. The basic indicators of tourist and recreational activities in the Transcarpathian region.

\begin{tabular}{ccccc}
\hline No. & Name of the District or Town & $\begin{array}{c}\text { The Number of } \\
\text { Tourists and } \\
\text { Vacationers, Thous }\end{array}$ & $\begin{array}{c}\text { The Number of Travel } \\
\text { Days, Thous }\end{array}$ & $\begin{array}{c}\text { The Volume of Provided } \\
\text { Tourist and Recreational } \\
\text { Services, Thous. UAH }\end{array}$ \\
\hline 1 & Berehove district & 85,293 & 203,835 & 3527.6 \\
2 & Velykobereznianskyi district & & no data available & 1004.1 \\
3 & Vynohradiv district & 2268 & 3491 & 793.7 \\
4 & Volovets district & 3327 & 7544 & 641.7 \\
5 & Irshava district & 2118 & 16,627 & 9567.6 \\
6 & Mizhhirya district & 13,771 & 57,041 & $96,586.7$ \\
7 & Mukachevo district & 26,677 & 291,118 & 7001.6 \\
8 & Perechyn district & 4739 & 76,474 & $13,571.7$ \\
9 & Rakhiv district & 26,550 & 73,122 & $140,348.7$ \\
10 & Svaliava district & 25,229 & 317,696 & 7490.0 \\
11 & Tyachiv district & 32,595 & 66,567 & 6287.7 \\
12 & Uzhhorod district & 9955 & 26,416 & $36,989.7$ \\
13 & Khust district & 63,478 & 172,089 & $14,659.7$ \\
14 & Uzhhorod & 22,532 & 36,867 & 1684.4 \\
15 & Mukachevo & 8753 & 10,351 & 2748.3 \\
17 & Khust & 5433 & 19,506 & 1527.9 \\
& Berehove & 5817 & 12,518 & $344,431.1$ \\
\hline
\end{tabular}

If we analyze the initial data from Table 1 , we can conclude that at the first stage of construction the tourist narrow-gauge railway line should be laid on the route: BerehoveKhmelnyk-Vynohradiv-Khust-Mizhhirya-Lysychovo-Svaliava. At the second launch area of construction, one should extend the narrow-gauge line on the route Svalyava-MukachevoIrshava and therefore to make the ring railway line. One can also complete the construction of the narrow-gauge line in the area Irshava-Lysychovo that will enable the development of this region.

It should be said that tourism and recreational activities in the Transcarpathian region for the previous reporting years several times exceeded the volumes presented in Table 1. Therefore, further research will take into account all the tourists, living in private hotels and apartments, as well as the additional flow of potential passengers, who will come to 
Transcarpathia to travel the new railway. The number of these potential tourists can be up to 2 million people.

Some demand for the railway transportation already exists, but one should conduct the basic marketing research to identify this demand. Table 2 presents the estimated indicators of demand for transfer and tourist transportations by the narrow-gauge lines.

Table 2. Estimated indicators of the tourism and recreational activities in the Transcarpathian region at the 1st stage of construction.

\begin{tabular}{|c|c|c|}
\hline No. & Name of the District or Town & $\begin{array}{l}\text { The Number of Tourists } \\
\text { and Vacationers, Thous. }\end{array}$ \\
\hline & $\begin{array}{l}\text { stimated number of tourists and vacationers who are the potential customers } \\
\text { narrow-gauge railway }\end{array}$ & \\
\hline 1 & Berehove district & 255 \\
\hline 2 & Velykobereznianskyi district & 20 \\
\hline 3 & Vynohradiv district & 7 \\
\hline 4 & Volovets district & 11 \\
\hline 5 & Irshava district & 7 \\
\hline 6 & Mizhhirya district & 45 \\
\hline 7 & Mukachevo district & 78 \\
\hline 8 & Perechyn district & 15 \\
\hline 9 & Rakhiv district & 79 \\
\hline 10 & Svaliava district & 90 \\
\hline 11 & Tyachiv district & 99 \\
\hline 12 & Uzhhorod district & 35 \\
\hline 13 & Khust district & 170 \\
\hline 14 & Uzhhorod & 69 \\
\hline 15 & Mukachevo & 32 \\
\hline 16 & Khust & 17 \\
\hline \multirow[t]{4}{*}{17} & Berehove & 21 \\
\hline & Total number of tourists and vacationers & 1050 \\
\hline & The estimated number of tourists who will use the narrow-gauge railway & 63 \\
\hline & The tourists who will use the narrow-gauge railway & \\
\hline 1 & Pupils of Ukrainian schools & 3 \\
\hline 2 & Students & 4 \\
\hline 3 & Residents of Ukraine & 20 \\
\hline \multirow[t]{2}{*}{4} & Representatives of neighboring European countries & 6 \\
\hline & Total estimated number of tourists who will use the narrow-gauge railway & 96 \\
\hline
\end{tabular}

Table 2 presents the estimated number of tourists who have the opportunity to travel by narrow-gauge lines. However, if one calculates the rolling stock for this number of potential customers, it will need large investments. Therefore, for the first stage of construction it is proposed to purchase only six railcars and five tourist trains, which will consist of two cars of the second class, one car of the first class, dining car, maintenance car, and the train locomotive. It is proposed to determine the possible number of transported tourists on the basis of the total capacity of these cars, their travel term, the number of journeys per year, and average annual train occupancy (Table 3).

At this, it is proposed the following movement organization of rolling stock on the narrow gauges:

On the route Svaliava- Lysychovo-Mizhhirya will be organized three journeys of the railcars per day with a capacity of 24 seats in each. A total of 525 such excursions per year is expected. The railcars are also supposed to be used for transfer transportations of the tourists who came by the broad gauge from the stations Svaliava and Mukachevo to tourist sites and, in addition, for transportation of tourists, residents of cities and villages, and of hotels and restaurant employees that have access to the narrow-gauge railway. 
Table 3. Calculation of the estimated number of tourists who will have the opportunity to travel by the narrow-gauge lines upon the condition of using the capacity of the available rolling stock, provided certain traffic management.

\begin{tabular}{|c|c|c|c|c|c|c|}
\hline Name of Route & $\begin{array}{l}\text { Number of } \\
\text { Seats in } \\
\text { Rolling } \\
\text { Stock }\end{array}$ & $\begin{array}{l}\text { The Type of } \\
\text { Rolling Stock }\end{array}$ & $\begin{array}{l}\text { The Number of } \\
\text { Journeys per } \\
\text { Day, Units }\end{array}$ & $\begin{array}{l}\text { The Number of } \\
\text { Journeys per } \\
\text { Year, Units }\end{array}$ & $\begin{array}{c}\text { Fill Factor of } \\
\text { the Rolling } \\
\text { Stock }\end{array}$ & $\begin{array}{c}\text { Total } \\
\text { Number of } \\
\text { Tourists, } \\
\text { Units }\end{array}$ \\
\hline $\begin{array}{l}\text { Svaliava-Lysychovo- } \\
\text { Mizhhirya }\end{array}$ & 24 & Railcar & 3 & 175 & 1 & 12,600 \\
\hline $\begin{array}{l}\text { Transfer transportations of } \\
\text { passengers between stations } \\
\text { and hotels including the } \\
\text { workers and local population }\end{array}$ & 24 & Railcar & 6 & 300 & 0.7 & 30,240 \\
\hline $\begin{array}{c}\text { Svaliava-Mukachevo-Irshava- } \\
\text { Berehove }\end{array}$ & 64 & $\begin{array}{l}\text { Train with } 2 \text { cars } \\
\text { of the second } \\
\text { class and } 1 \text { car of } \\
\text { the first class }\end{array}$ & 1 & 300 & 0.8 & 15,360 \\
\hline $\begin{array}{l}\text { Berehove-Khmelnyk- } \\
\text { Vynohradiv-Khust- } \\
\text { Mizhhirya-Lysychovo- } \\
\text { Svaliava }\end{array}$ & 64 & $\begin{array}{l}\text { Train with } 2 \text { cars } \\
\text { of the second } \\
\text { class and } 1 \text { car of } \\
\text { the first class }\end{array}$ & 1 & 450 & 0.8 & 23,040 \\
\hline Total & & & & & & 81,240 \\
\hline
\end{tabular}

For the two-day route Svaliava-Mukachevo-Irshava-Khmelnyk-Berehove and return, it is supposed to use the narrow-gauge train with five cars (two cars of the second class, one car of the first class, dining car, and the special car) having 64 seats. For this route, there will be involved two rolling stocks running every other day.

The route Berehove-Khmelnyk-Vynohradiv-Khust-Mizhhirya-Lysychovo-Svaliava is intended for 3 days. This direction also provides the use of the narrow-gauge train of five cars (two cars of the second class, one car of the first class, dining car, and the special car) having 64 seats.

Firstly, one should determine the most attractive routes for tourist travels by railway. On the basis of the above-mentioned at the first stage of construction of the narrowgauge railway, the following routes can be proposed: Svaliava-Lysychovo (length $30 \mathrm{~km}$ ), Lysychovo-Mizhhirya (24 km), Mizhhirya-Khust (60 km), Khust-Vinohradiv (25 km), Vinohradiv-Khmilnyk (19.6 km), Khmilnyk-Berehove (25 km), Khmilnyk-Irshava (15 km), Irshava-Mukachevo (33 km), and Mukachevo-Svalyava (26 km). In these towns, the stop of tourist trains or railcars is provided.

The tourist train stops at the stations for landing the tourists who transfer to the minibuses or the ordinary buses, the capacity of which corresponds to the number of tourists who want to continue the tour. After each tour, a group of tourists boards the bus and goes to the restaurant or to the railway station and then travels by train. At the end of the day, the train brings tourists to the hotel (apartments) for their rest and meals. The price includes accommodation in a hotel and morning breakfast. After that, tourists go to the city excursions, and then buses bring them to the railway station.

For tourist meals during the travel, the train additionally includes a dining car, or the buffet car depending on the length of the route and class of the train. Afterward, the tour buses bring the tourists from the terminal station to the hotel. Thus, throughout the tour, buses carry out the transfer transportation of tourists from the trains to tourist sites, restaurant, hotel, and return.

On the route Svaliava-Lysychovo-Mizhhirya, the railcars can perform the tourist transportation by small groups of 16 or 24 people. They transport tourists by both the railway and the road that is very convenient because there is no need to change the train for minibuses. If the number of tourists will increase, on the given route can be introduced the running of tourist trains of three cars (including two cars of the second class). 
Table 4. Calculation of the total revenue of tourism company from transfer and tourist transportation by narrow-gauge railways.

\begin{tabular}{|c|c|c|c|c|}
\hline Name of Route & $\begin{array}{c}\text { Total Number of } \\
\text { Tourists }\end{array}$ & $\begin{array}{l}\text { The Average Cost of } \\
\text { the Ticket or Transfer, } \\
\text { UAN }\end{array}$ & $\begin{array}{l}\text { Total Revenue on } \\
\text { the Route, UAN }\end{array}$ & $\begin{array}{l}\text { Total Revenue on } \\
\text { the Route, USD }\end{array}$ \\
\hline Svaliava-Lysychovo-Mizhhirya & 12,600 & 400 & $5,040,000$ & 201,600 \\
\hline $\begin{array}{l}\text { Transfer transportations of passengers } \\
\text { between stations and hotels including } \\
\text { the workers and local population }\end{array}$ & 30,240 & 70 & $2,116,800$ & 84,672 \\
\hline Svaliava-Mukachevo-Irshava-Berehove & 15,360 & 1400 & $21,504,000$ & 860,160 \\
\hline $\begin{array}{c}\text { Berehove-Khmelnyk-Vynohradiv- } \\
\text { Khust-Mizhhirya-Lysychovo- } \\
\text { Svaliava }\end{array}$ & 23,040 & 2000 & $46,080,000$ & $1,843,200$ \\
\hline Total & 81,240 & & $74,740,800$ & $2,989,632$ \\
\hline
\end{tabular}

Taking into account the mentioned estimated flow of tourists, the revenue of the railway company from tourist and transfer transportations can be calculated (Table 4).

As a result of the proposed measures, one can expect an increase of passenger traffic on the railroad, image improvement of the railways within the country and abroad, attraction of additional funds to renew the outdated infrastructure and rolling stock, restoration of the objects of cultural and historical significance, and the creation of new jobs.

The authors propose further development of the purpose exploitation of the railway transport as a separate kind of the economy with the provision of the classification of the main types of the railway tourism: cruise and sightseeing ones, transfer transportation on the wide- and narrow-gauge lines.

The authors propose to construct a railway tourism ring in Ukraine on the narrowgauge line according to the route: Svaliava-Mukachevo-Irshava-Beregovo-VinogradovoKhust-Mizhhirya.

This paper is the first in the railway tourism sphere to put under research a task of making an economic-mathematical model of discrete optimal planning. The latter is elaborated for determining sets of effective routes, which are the most profitable ones while meeting the established system of requirements, that restricts tourist operators' activity. The preconditions of such a task are determined by the following. On the railway polygon there usually exists a track of $62 \mathrm{~km}$ long; in addition, it is planned to put $198 \mathrm{~km}$ of narrow gauge. Such measures will allow to include into the zone of the tourist railway a majority of tourist objects which are located in the stations of Beregove, Khmelnik, Vinogradiv, Irshava, Khust, Vuchkove, Mizhhirya, Lusuchovo, Svaliava, Mukachevo, and Dovge in Ukraine. The main characteristics of the project components are supposed to be known, namely, general cost of the passenger carriages, restrictions as for the general cost of the locomotives, carriages of the first class, carriages of the second class, carriage-buffets, special carriages, and rail mobiles (Table 5).

In the planning, model tourist routes (Table 5) are represented by separate binary variables. From the content point of view, the task of the optimal planning includes determination of such variable values which meet the model restrictions and provide maximum evaluation of the profitability index (or another economics index of the tourist activity efficiency). 
Table 5. Variants of the possible routes, train structures, and the potential number of tourists.

\begin{tabular}{|c|c|c|c|c|c|c|c|c|}
\hline \multirow[b]{2}{*}{$\begin{array}{l}\text { Route } \\
\text { Number }\end{array}$} & \multirow[b]{2}{*}{ Route Name } & \multirow[b]{2}{*}{$\begin{array}{c}\text { Route } \\
\text { Duration }\end{array}$} & \multicolumn{5}{|c|}{ Rolling Stock } & \multirow[b]{2}{*}{$\begin{array}{l}\text { Total after } \\
\text { the First } \\
\text { Stage } \\
\text { Introduction }\end{array}$} \\
\hline & & & $\begin{array}{l}\text { The } \\
\text { Number of } \\
\text { Month, } \\
\text { Units }\end{array}$ & Type & $\begin{array}{l}\text { The } \\
\text { Number of } \\
\text { Units }\end{array}$ & $\begin{array}{l}\text { The } \\
\text { Number of } \\
\text { Trips per } \\
\text { Year }\end{array}$ & $\begin{array}{l}\text { Coefficient } \\
\text { of Usage }\end{array}$ & \\
\hline 1 & $\begin{array}{l}\text { Svalyava- } \\
\text { Lusuchovo- } \\
\text { Mizhgirya- } \\
\text { Svalyava }\end{array}$ & 1 & 24 & Railmobile & 2 & 300 & 0.8 & 11,520 \\
\hline 3 & $\begin{array}{c}\text { Svalyava- } \\
\text { Mizhgirye-Khust- } \\
\text { Lusuchkovo- } \\
\text { Svalyava }\end{array}$ & 2 & 50 & $\begin{array}{c}\text { Train of } 4 \\
\text { carriages ( } 2 \\
\text { carriages of the } \\
\text { second class) }\end{array}$ & 2 & 150 & 0.8 & 12,000 \\
\hline 4 & $\begin{array}{c}\text { Svalyava- } \\
\text { Mizhgirya-Khust- } \\
\text { Beregove (one } \\
\text { way) }\end{array}$ & 2 & 64 & $\begin{array}{c}\text { Train of } 5 \\
\text { carriages ( } 2 \\
\text { carriages of the } \\
2 \text { nd class, } 1 \text { car } \\
\text { of the first class }\end{array}$ & 2 & 150 & 0.8 & 15,360 \\
\hline 6 & $\begin{array}{c}\text { Svalyava- } \\
\text { Lusuchovo- } \\
\text { Mizhgirye-Khust- } \\
\text { Vinogradiv- } \\
\text { Khmelnik- } \\
\text { Beregove- } \\
\text { Vinogradiv (one } \\
\text { way) }\end{array}$ & 3 & 56 & $\begin{array}{l}\text { The train } \\
\text { "Pearl of } \\
\text { Carpathians" } \\
\text { (4 cars of the } \\
\text { first class) }\end{array}$ & 2 & 100 & 0.9 & 10,080 \\
\hline 9 & $\begin{array}{c}\text { Svalyava- } \\
\text { Lusuchovo- } \\
\text { Mizhgirye- } \\
\text { Vuchkive-Khust- } \\
\text { Vinogradiv- } \\
\text { Khmelnik- } \\
\text { Beregove (one } \\
\text { way) }\end{array}$ & 3 & 100 & $\begin{array}{l}\text { Train of } 6 \\
\text { carriages } \\
\text { (4 carriages of } \\
\text { the second } \\
\text { class) }\end{array}$ & 2 & 100 & 0.9 & 18,000 \\
\hline
\end{tabular}

Source: development of authors.

As for the calculation of the potential tourist numbers, the authors propose different methods for the railways of different gauges. Thus, for the wide-gauge line, the authors suggest the use of the following formula:

$$
\mathrm{PKT}=\mathrm{KPT} * \mathrm{~K}_{\mathrm{d}} * \mathrm{~K}_{\mathrm{inf}}
$$

Here, PKT is the proposed tourist number;

$\mathrm{KPT}$ is the tourist number in the reported year who used any kind of tourism according the state statistic service, in the tourist number;

$K_{d}$ is the coefficient which includes an annual demand for the railway trips. It is calculated according the result of the anonymous questionnaire;

$\mathrm{K}_{\text {inf }}$ is the coefficient which includes the present railway infrastructure as for the tourism objects. This is determined provided the time of the tourist bus transportation is no more than an hour.

The prospective number of tourist who will use narrow-gauge lines can be calculated according the formula:

$$
\mathrm{PKT}=\mathrm{PKVG} * \mathrm{~K}_{\text {tour.year }}+\mathrm{PKPR} * \mathrm{~K}_{\text {pr.tour }}+\mathrm{PKMM} * \mathrm{~K}_{\text {local }}
$$

Here, PKT is a prognosis of the tourist number in the railway transportation who will use local hotels, private apartments and railway transfer during the year;

$\mathrm{K}_{\text {tour. year }}$ is a prognosis coefficient which includes fluctuations of the tourist number during a year; 
PKPR is a prognosis number of the staff which will work at the tourist object and which will use railway transportation during a year;

$\mathrm{K}_{\text {tour.year }}$ is a prognosis coefficient which includes fluctuations of the number of the service staff during a year;

PKMM is a prognosis number of the local residents who will use railway transportation during a year; it is determined according to the population number in the zone of the transportation with taking into account a coefficient which included a part of the population which will use this railway, the number of people;

$\mathrm{K}_{\text {local }}$ is a prognosis coefficient which includes fluctuations of the local residents who will use the railway during a year.

The proposed scientific approach as for determining the prospective number of potential tourists allows estimating the long-term amount of the passenger transportation, the structure of the railway rolling stock, and the fleet of rail mobiles and automobile transfers. Nowadays, this approach is not present in Ukraine because railway tourism on the narrow-gauge lines is a single character.

The results of the calculated net value of the given routes according to Table 4 and the formula NPV $=-I_{0}+\sum\left(\prod_{k}-B_{k}\right) /(1+i)^{n}$ are given in Table 6 . In this, $i$ is a discount stake, an accepted $i=11$.

Table 6. Money Flow before and after Re-Distribution of the Annual Expenses.

\begin{tabular}{ccc}
\hline The Route Number & Money Flow before and after Re-Distribution of the Annual Expenses, in Thousands, US Dollars \\
\hline 1 & 93,081 & 36,204 \\
2 & $534,739,53$ & $-143,456,79$ \\
\hline
\end{tabular}

Source: development of authors.

Thus, the re-distribution of the planned annual expenses and money flows results in substantial changes of the given net value of every project for tourism route development (Table 7).

Table 7. Redistributed annual costs and cash flow conditional tourist routes.

\begin{tabular}{cccccc}
\hline The Route Number & $\mathbf{I}_{\mathbf{0}}$ & $\mathbf{B}_{\mathbf{1}}$ & $\mathbf{B}_{\mathbf{2}}$ & $\mathbf{B}_{\mathbf{3}}$ & $\mathbf{B}_{\mathbf{4}}$ \\
\hline 1 & 22,478 & 50,000 & 50,000 & 91,000 & $35,483.2$ \\
2 & 15,000 & 500,000 & 500,000 & $2,000,000$ & $\Pi_{3}$ \\
\hline The Route Number & $\mathbf{I}_{\mathbf{0}}$ & $\Pi_{\mathbf{1}}$ & $\Pi_{\mathbf{2}}$ & $\Pi_{\mathbf{3}}$ & $\Pi_{\mathbf{4}}$ \\
\hline 1 & 22,478 & 20,000 & 27,560 & 175,000 & 100,000 \\
2 & 15,000 & 500,000 & $1,128,800$ & 800,000 & $1,200,000$ \\
\hline
\end{tabular}

Source: development of authors.

We are to give a conventional calculation as for two-stage models in order to choose an optimal variant. For example, it is necessary to choose a better route from two chosen ones, taking into consideration uncertainty of the number of tourists (Table 8).

Table 8. Initial data for two-stage conditional planning models tourist routes.

\begin{tabular}{ccccc}
\hline \multirow{2}{*}{ The Route Number } & Expenses, in & \multicolumn{3}{c}{ The Number of Tourists, People } \\
\cline { 3 - 5 } & $\begin{array}{c}\text { Thousands, US } \\
\text { Dollars }\end{array}$ & $\mathbf{1 0 0 0 - 3 0 0 0}$ & $\mathbf{3 0 0 0 - 8 0 0 0}$ & $\mathbf{8 0 0 0 - 1 2 0 0 0}$ \\
\cline { 3 - 5 } & & Certainty $=\mathbf{0 . 2}$ & Certainty = 0.1 & Certainty = 0.7 \\
\cline { 3 - 5 } & $226,483.2$ & Income 1, Dollars & Income 2, Dollars & Income 3, Dollars \\
\hline 1 & $2,839,737.6$ & 80,640 & 161,280 & 322,560 \\
\hline 2 & 907,200 & $1,814,400$ & $3,628,800$ \\
\hline
\end{tabular}

Source: development of authors. 
The results of the calculations in Tables 6 and 9 represent considerable planning possibilities of tourism operators' activities thanks to the optimal choice of the succession of routes introduction. It should be performed on the basis of the models of the tourism potential development which are proposed in this paper.

Table 9. The Money Flow with the Account of the Uncertainty of the Tourists Quantity.

The Route Number

1

2

The Money Flow with the Account of the Uncertainty of the Tourists Quantity, Thousand Dollars

$31,564.8$

$63,302.4$

Source: development of authors.

\section{Conclusions}

The tourist industry influences the key industries of economics, such as transport and communications, trade, hotels and restaurants, health care, and agriculture. Tourism is closely connected with the use of historical and natural heritage, study of traditions and cultures of different countries, and is therefore a good example of how to coordinate problem solving of economic growth and sustainable development.

Solving this problem requires a careful study of the existing possibilities and potential development of railway transport, identifying the use areas of its mode when organizing tourist traffic.

After mitigating quarantine restrictions it is expected that the tourism industry will be restored. At the same time, there will be a new development of spheres of production and service involved in the organization of passenger transportation. Given the global trends toward the sustainable development of society, there are prerequisites for the usage of railway transport for tourist needs. This will add attractiveness to the rail sector and optimize the work of operating companies. For more efficient planning of railway travel, a system of organizational and functional support of development for railway tourism is offered, and multi-stage economic and mathematical models are developed. They will allow us to take risks into account when planning tourist routes by rail, determine the order of construction or start of routes, and assess their profitability. In further studies, a number of additional factors will be taken into account [67-69], which affect the optimal operation of companies concerning the organization of railway tourism transportation.

Here we mean a wide range of risks-from falling demand for one or another tourist route from tourists' side to a sharp increase in the cost of tourist rolling stock by manufacturers and many other risks.

The article presents economic-mathematical models of multi-stage planning for the optimal development of the railway tourism sphere on any railway polygon, near which there is already a developed tourist infrastructure or it is possible to build it. At the same time, on the basis of two-stage models of discrete mathematical programming with regards to the possible risks, we determined optimal (according to the criterion of net present value) railway tourist routes by railway. The system of constraints of models takes into consideration the requirements for rolling stock, the number of tourists and trips; the volume of investments under the stages of the project implementation, requirements for the number of certain categories of routes, and suchlike.

The proposed methodology is grounded on the connectivity law of the railway network, the independence of the functioning of individual tourist routes, additivity of the functions in assessing the performance of companies that would organize the railway tourism.

Originality is to obtain new economic and mathematical models and algorithms of multi-stage planning for the processes of tourist companies or investors, in the light of risks providing an ordered selection of optimal (according to the criterion of net present value) routes of the railway tourism. 
The results of the research provide opportunities for optimizing the processes of planning of the railway tourism development, which is determined by optimal ordering in the sequence of introducing railway tourist routes in action from a certain group of pre-planned routes. In doing so, it is assumed to manage risks of possible disturbances of the planning model parameters, which determines the indicated sphere of activity.

The results of the research provide the possibility of improving the efficiency of tourist railway operator companies at the stage of determining and choosing the sphere of activity.

The results of our planning models realization include the task of the succession of the railway tourism routes due to the present and future infrastructure, availability of the rolling stock etc., which provide maximum planned income for every participant in the tourism operation for a definite period. The calculation samples, which are represented here, show certain possibilities of the proposed models for the choice of the succession of the railway tourism routes as a factor of the development of the regional tourism potential.

The economic-mathematical models proposed by the authors have successfully passed the approbation period in Ukraine. In this article some complex issues, which should be solved while developing models, are noted. Taking into consideration some recommendations of the law-abiding character, the complex research is done as for the development of the tourist branch of economy in Ukraine. Firstly, the full revision of all narrow-gauge railways has been made in the Zakarpatsky region. Secondly, the analysis of the places of tourism and recreation has been performed with the calculation of the visit numbers for year. Thirdly, the tourist rolling stock has been designed, that consists of contemporary carriages of different application. Fourthly, ten tourists routes of different length have been developed for the designed tourist ring. The planning model, mentioned above, is designed for substantiation of the step-by-step introduction of the proposed tourist routes with the aim of the most profitability from their usage.

Author Contributions: The authors equally contributed to the present research and to the preparation of the paper. All authors have read and agreed to the published version of the manuscript.

Funding: This research received no external funding.

Institutional Review Board Statement: Not applicable.

Informed Consent Statement: Not applicable.

Data Availability Statement: Not applicable.

Acknowledgments: This work was related to the D.D. 407 of 27 February 2018 "AIM-Attrazione e Mobilitaà Internazionale" issued by the Italian Ministry of Education, University, and Research in the implementation of Action I.2 "Mobilitaà dei Ricercatori" Asse I-PON R\&I 2014-2020, taking into account the written amendment procedure of the PON R\&I 2014-2020, pursuant to articles 30 and 90 of Regulation (EU) 1303/2013 started on 21 February 2018 as well as the relevant implementation regulations.

Conflicts of Interest: The authors declare no conflict of interest.

\section{References}

1. Ollero, J.L.S.; Capellan, R.U.; García-Pozo, A. The impact of cultural and urban tourism on housing. J. Tour. Herit. Res. 2019, 2, 257-272. Available online: http:/ / www.jthr.es/index.php/journal/article/view/113 (accessed on 15 April 2021).

2. Safety Database-UIC. International Union of Railways; UIC Safety Report: Paris, France, 2020. Available online: safetydb.uic.org (accessed on 18 March 2021).

3. Chen, C.-M.; Chen, Y.C. Income source effect on retiree's tourism behavior. Ann. Tour. Res. 2018, 68, 4-6. [CrossRef]

4. Konstantakis, K.N.; Soklis, G.; Michaelides, P.G. Tourism expenditures and crisis transmission: A general equilibrium GVAR analysis with network theory. Ann. Tour. Res. 2017, 66, 74-94. [CrossRef]

5. Curto, S.; Severino, A.; Trubia, S.; Arena, F.; Puleo, L. The effects of autonomous vehicles on safety. AIP Conf. Proc. 2021, 2343, 110013. [CrossRef]

6. Zelenko, Y.; Zelenko, D.; Neduzha, L. Contemporary principles for solving the problem in noise reduction from railway rolling stock. IOP Conf. Ser. Mater. Sci. Eng. 2020, 985, 012015. [CrossRef]

7. Huber, D.; Milne, S.; Hyde, K.F. Constraints and facilitators for senior tourism. Tour. Manag. Perspect. 2018, 27, 55-67. [CrossRef] 
8. Global Rail Market Continues to Grow Despite Drop in Transport Volumes due to COVID-19. STUDY UNIFE World Rail Market 2020. Available online: www.rolandberger.com (accessed on 18 April 2021).

9. Shaikh, M.; Qamari, I.N. Covid-19 and its Impact on the Global Tourism Industry. J. Contemp. Issues Bus. Gov. 2021, 27, 2297-2306.

10. Uğur, N.G.; Akbıyık, A. Impacts of COVID-19 on global tourism industry: A cross-regional comparison. Tour. Manag. Perspect. 2020, 36, 100744. [CrossRef]

11. Anđelić, N.; Šegota, S.B.; Lorencin, I.; Mrzljak, V.; Car, Z. Estimation of COVID-19 epidemic curves using genetic programming algorithm. Health Inform. J. 2021, 27, 1460458220976728. [CrossRef]

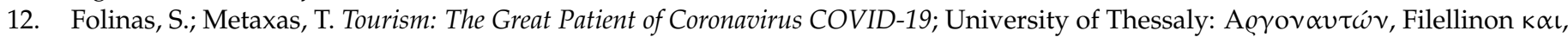
Greece, 2020; pp. 1-13.

13. Öz Ceviz, N.; Tektaş, N.; Basmacı, G.; Tektaş, M. Covid 19 pandemi sürecinde üniversite öğrencilerinin kaygı düzeylerini etkileyen değişkenlerin analizi. Uluslararası Ĕ̆itim Araştırmacıları Derg. 2020, 3, 312-329.

14. Wang, D.; Niu, Y.; Qian, J. Evolution and optimization of China's urban tourism spatial structure: A high speed rail perspective. Tour. Manag. 2018, 64, 218-232. [CrossRef]

15. Procházka, J.; Hošková-Mayerová, Š.; Procházková, D. The risks connected with accidents on highways and railways. Qual. Quant. Int. J. Methodol. 2020, 54, 1537-1548. [CrossRef]

16. Aydina, O. Tourism Income of Turkey: A Panel Data Approach. Procedia Econ. Financ. 2016, 38, 245-256. [CrossRef]

17. Camargo, B.A.; Garza, C.C.; Morales, M. Railway Tourism: An Opportunity to Diversify Tourism in Mexico. Chapter. Railw. Herit. Tour. 2014, 151-165. [CrossRef]

18. González-Ramiro, A.; Gonçalves, G.; Sánchez-Ríos, A.; Jeong, J.S. Using a VGI and GIS-Based Multicriteria Approach for Assessing the Potential of Rural Tourism in Extremadura (Spain). Sustainability 2016, 8, 1144. [CrossRef]

19. Gligorijević, Ž.; Novović, M. Health And Recreation Tourism In The Development Of Mountain Spas And Resorts. Econ. Themes 2014, 52. [CrossRef]

20. Alam, M.S.; Paramati, S.R. The impact of tourism on income inequality in developing economies: Does Kuznets curve hypothesis exist? Econ. Ann. Tour. Res. 2016, 61, 111-126. [CrossRef]

21. Stauvermann, P.J.; Kumar, R.R. Productivity growth and income in the tourism sector: Role of tourism demand and human capital investment. Tour. Manag. 2017, 61, 426-433. [CrossRef]

22. Li Kevin, X.; Jin, M.; Shi, W. Tourism as an important impetus to promoting economic growth: A critical review. Tour. Manag. Perspect. 2018, 26, 135-142. [CrossRef]

23. Dogru, T.; Bulut, U. Is tourism an engine for economic recovery? Theory and empirical evidence. Tour. Manag. 2018, 67, 425-434. [CrossRef]

24. Chai, J.; Zhou, Y.; Zhou, X.; Wang, S.; Zhang, Z.G.; Liu, Z. Analysis on shock effect of China's high-speed railway on aviation transport. Transp. Res. Part A Policy Pract. 2018, 108, 35-44. [CrossRef]

25. Sokhanvar, A.; Çiftçioğlu, S.; Javid, E. Another look at tourism-economic development nexus. Tour. Manag. Perspect. 2018, 26, 97-106. [CrossRef]

26. MacNeill, T.; Wozniak, D. The economic, social, and environmental impacts of cruise tourism. Tour. Manag. 2018, 66, 387-404. [CrossRef]

27. Dutt, C.S.; Harvey, W.S.; Shaw, G. The missing voices in the perceptions of tourism: The neglect of expatriates. Tour. Manag. Perspect. 2018, 26, 193-202. [CrossRef]

28. Kumar, N.; Kumar, R.R.; Patel, A.; Shahzad, S.J.H.; Stauvermannб, P.J. Modelling inbound international tourism demand in small Pacific Island countries. Appl. Econ. 2020, 52, 1031-1047. [CrossRef]

29. Saleem, H.; Jiandong, W.; Zaman, K.; Elashkar, E.; Elsherbini, S.A.M. The impact of air-railways transportation, energy demand, bilateral aid flows, and population density on environmental degradation: Evidence from a panel of next-11 countries. Transp. Res. Part D Transp. Environ. 2018, 62, 152-168. [CrossRef]

30. Jensen, M.T.; Scarles, C.; Cohen, S. A multisensory phenomenology of interrail mobilities. Ann. Tour. Res. 2015, 53, 61-76. [CrossRef]

31. Tyagi, A.; Dhar Rajib, L.; Sharma, J. Police culture, tourists and destinations: A study of Uttarakhand, India. Tour. Manag. 2016, 52, 563-573. [CrossRef]

32. Barbosa, H.; Barthelemy, M.; Ghoshal, G.; James, C.R.; Lenormand, M.; Louail, T.; Menezes, R.; Ramasco, J.J.; Simini, F.; Tomasini, M. Human mobility: Models and applications. Phys. Rep. 2018, 734, 1-74. [CrossRef]

33. Li, Z.; Zhou, X.; Gu, A.; Li, Q. A complete approach for CIM modelling and model formalising. Inf. Softw. Technol. 2015, 65, 39-55. [CrossRef]

34. Conlin, M.V.; Geoffrey, R. Bird Railway Heritage and Tourism: Global Perspectives; Channel View Publications: Bristol, UK, 2014; 298p.

35. Su, M.M.; Wall, G. The Qinghai-Tibet railway and Tibetan tourism: Travelers' perspectives. Tour. Manag. 2009, 30, 650-657. [CrossRef]

36. Lingaitis, V.; Sinkevicius, G. Passenger Transport by Railway: Evaluation of Economic and Social Phenomenon. Procedia Soc. Behav. Sci. 2014, 110, 549-559. [CrossRef]

37. Palmisano, G.O.; Govindanb, K.; Loisi, R.V.; Sasso, P.D.; Roma, R. Greenways for rural sustainable development: An integrationbetween geographic information systems and group analytichierarchy process. Land Use Policy 2016, 50, 429-440. [CrossRef] 
38. Wang, R.; Yang, K.; Yang, L.; Gao, Z. Modeling and optimization of a road-rail intermodal transport system under uncertain information. Eng. Appl. Artif. Intell. 2018, 72, 423-436. [CrossRef]

39. Salvucci, R.; Tattini, J.; Gargiulo, M.; Lehtila, A.; Karlsson, K. Modelling transport modal shift in TIMES models through elasticities of substitution. Appl. Energy 2018, 232, 740-751. [CrossRef]

40. Guerrieri, M.; Ticali, D. Design standards for converting unused railway lines into greenways. ICSDC 2011 Integr. Sustain. Pract. Constr. Ind. 2012, 654-660. [CrossRef]

41. Utsunomiya, K. The value of local railways: An approach using the contingent valuation method. Res. Transp. Econ. 2018, 69, 554-559. [CrossRef]

42. Bertolini, L.; Spit, T. Cities on Rails: The Redevelopment of Station Areas; Spon: London, UK, 1998; 256p.

43. Ferretti, V.; Degioanni, A. How to support the design and evaluation of redevelopment projects for disused railways? A methodological proposal and key lessons. Transp. Res. Part 2017, 52, 29-48. [CrossRef]

44. Ruocco, G.D.; Sicignano, E.; Fiore, P.; D'Andria, E. Sustainable Reuse of Disused Railway. Procedia Eng. 2017, 180 , 1643-1652. [CrossRef]

45. Konovalova, T.; Zarovnaya, L. The Assessment Model for Economic Efficiency of Traffic Safety Improvements. Transp. Res. Procedia 2017, 20, 311-315. [CrossRef]

46. Cranenburgh, S.; Chorus, C.G. Does the Decision Rule Matter For Large-Scale Transport Models? Transp. Res. Procedia 2017, 23, 848-867. [CrossRef]

47. Vujović, M.; Premović, Đ.J.; Spajić, R. Sustainability aspects of managerial process of creating material basis for tourism. Business 2018, 48, 297-310. [CrossRef]

48. Flores-Romero, M.B.; Perez-Romero, M.E.; García, J.Á.; del Río-Rama, M.d.l.C. Fuzzy Techniques Applied to the Analysis of the Causes and Effects of Tourism Competitiveness. Mathematics 2021, 7, 777. [CrossRef]

49. Martseniuk, L.V.; Polyshko, T.V. Examples of organization of tourist rail transportation in different countries of the world. AgroSvit 2016, 10, 31-42.

50. Ranasinghe, R.; Cheng, L. Tourism-Driven Mobilities: Scale Development Approach in Postwar Growth Setting in Sri Lanka. Source Title Int. J. Asian Bus. Inf. Manag. 2020, 11, 1-16. [CrossRef]

51. Ozturk, O.; Patrick, J. An optimization model for freight transport using urban rail transit. Eur. J. Oper. Res. 2018, 267, 1110-1121. [CrossRef]

52. Diaz, M.; Josefa, M.; Peidro, M.D. A mathematical programming model for integrating production and procurement transport decisions. Appl. Math. Model. 2017, 52, 527-543. [CrossRef]

53. Robson, E.N.; Wijayaratna, K.P.; Dixit, V.V. A review of computable general equilibrium models for transport and their applications in appraisal. Transp. Res. Part A Policy Pract. 2018, 116, 31-53. [CrossRef]

54. Nilnoppakun, A.A.; Ampavat, K.A. Integrating Cultural and Nostalgia Tourism to Initiate A Quality Tourism Experiences at Chiangkan, Leuy Province, Thailand. Procedia Econ. Financ. 2015, 23, 763-771. [CrossRef]

55. Lew, A.; McKercher, B. Modeling tourist movements: A Local Destination Analysis. Ann. Tour. Res. 2006, 33, 403-423. [CrossRef]

56. Truong, N.V.; Shimizu, T. The effect of transportation on tourism promotion: Literature review on application of the Computable General Equilibrium (CGE) Model. Transp. Res. Procedia 2017, 25, 3096-3115. [CrossRef]

57. Michniak, D. Narrow-gauge railways in Slovakia and their use for tourism purposes. Pract. Kom. Geogr. Komun. PTG 2018, 21, 9-16. [CrossRef]

58. Bašić, Z.; Džananović, A. Route Tourist Railway Banovići-Zlača. Arch. Tech. Sci. 2018, 1, 49-54. [CrossRef]

59. Allis, T.; Fraga, C.; Velazquez, M.A. Railway for Tourism in South America: An Approach on Its Uses. J. Traffic Transp. Eng. 2016, 4, 339-349. [CrossRef]

60. Domingos, Z.; Castro, B. Património e Arqueologia Angolana como potenciais aliados de uma atividade turística nacional residual. Afr. Studia Rev. Int. Estud. Afr. 2015, 24, 71-82.

61. Kampczyk, A. Geodäsie im Investitionsbauprozess auf den Bahngebieten in Polen. Bautechnik 2014, 91, 409-413. [CrossRef]

62. Berto, A.; Gliozzi, S. Unconstraining the Passenger Demand for Rail Yield Management at Trenitalia. Electron. Notes Discret. Math. 2018, 69, 269-276. [CrossRef]

63. Kozlowski, M.; Pawełczyk, M.J.; Piotrowska-Piątek, A. Innovativeness of railway transport in the context of the development of tourism in Poland. Qual. Quant. Int. J. Methodol. 2020, 54. [CrossRef]

64. Gálvez, A.; Seneviratne, D.; Galar, D. Hybrid Model Development for HVAC System in Transportation. Technologies 2021, 9, 18. [CrossRef]

65. Babyak, M.; Keršys, R.; Neduzha, L. Improving the dependability evaluation technique of a transport vehicle. In Proceedings of the Transport Means-Proceedings of the International Conference, Kaunas, Lithuania, 6-8 October 2021; pp. 646-651.

66. Kljaic, Z.; Cipek, M.; Mlinaric, T.J.; Pavkovic, D.; Zorc, D. Utilization of Track Condition Information from Remote Wireless Sensor Network in Railways-A Mountainous Rail Track Case Study. 27th Telecommunications Forum. TELFOR 2019, 8971066. [CrossRef]

67. Remesnik, E.S.; Sigal, A.V. Application of Fishburn Sequences in Economic and Mathematical Modeling. In International Scientific Conference "Far East Con" (ISCFEC 2020); Atlantis Press: Amsterdam, The Netherlands, 2020; pp. 2733-2737. [CrossRef] 
68. Macioszek, E.; Sierpin'ski, G.; Staniek, M.; Celin'ski, I. Transport planning, organization and management. In Proceedings of the 2nd World Congress on Civil, Structural, and Environmental Engineering, CSEE, Barcelona, Spain, 2-4 April 2017; Volume 1-8. [CrossRef]

69. Bedradina, G.; Nezdoyminov, S. Scientific and methodological basis of tourist services quality assessment. In Socio-Economic Research Bulletin; Odessa National Economic University: Odessa Oblast, Ukraine, 2018; pp. 63-72. [CrossRef] 